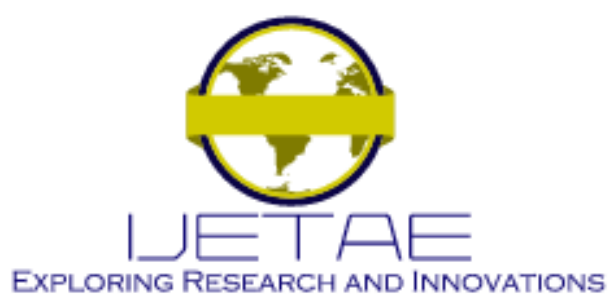

International Journal of Emerging Technology and Advanced Engineering

Website: www.ijetae.com (E-ISSN 2250-2459, Scopus Indexed, ISO 9001:2008 Certified Journal, Volume 12, Issue 01, January 2022)

Manuscript Received: 02 December 2021, Received in Revised form: 04 January 2022, Accepted: 10 January 2022

DOI: 10.46338/ijetae0122_10

\title{
Implementation of an Air Pollution Measurement System in Mining Areas of Cerro de Pasco-Peru
}

\author{
Wilhen Huaman-Hinostroza ${ }^{1}$, Brian Meneses-Claudio ${ }^{2}$, Alexi Delgado ${ }^{3}$ \\ ${ }^{1,2}$ Universidad de Ciencias y Humanidades \& Av. Universitaria 5175, Los Olivos 15304 \\ ${ }^{3}$ Pontificia Universidad Católica del Perú \& Av. Universitaria 1801, San Miguel 15088
}

\begin{abstract}
One of the big problems in the city of Cerro de Pasco is the air pollution caused by the mining activity that occurs in this area, this activity generates a total of 3737 metric tons per year of particulate matter, which are thrown into the environment in an alarming way, thus reaching that this particulate matter can lodge inside the organism of the inhabitants permanently, causing in them diseases in the respiratory system, thus affecting the most vulnerable population, producing in them infections in the respiratory tract that can even carry those to death. Nowadays the teams that carry out the monitoring of air quality are restricted only to the academic and governmental sphere, so much so that the population does not know the degree of air pollution. For this reason, it is proposed to carry out a system to measure the level of air pollution taking as main data, the measurement of particulate matter and the emission of carbon monoxide, the data that can be recovered from these measurements to be able to compare them with the parameters dictated by the Ministry of the Environment. As a result, an autonomous system was obtained, with which the level of particulate matter, possible toxic gases, and the measurement of the level of carbon monoxide can be measured, all these pollutants that could be in the environment, all these measurements are constant, thus leading the population to become aware of the level of quality of the environment where they live.
\end{abstract}

Keywords-- Environmental pollution, articulated matter, carbon monoxide, toxic gases, mining activity, air quality.

\section{INTRODUCTION}

Mining is a big problem, which this is no longer of now these are since ancient times, they prey on zonal destroying everything the habitat that is in it, not only that they also contaminate the vegetation producing in it the contamination of the water which is the means of survival of every living species in which we humans are.
This desire to exploit without measuring the consequences, entails a great problem in the areas of cultivation, as well as in those of grazing thus affecting all agricultural area which composes it in $40 \%$ of the plateau, as well as affects the area of livestock to which it is composed of $30 \%$ of all activity on the plateau, in all this it could be said that nature is losing to the greed that mining exploitation could generate. [1]

Artisanal scale mining is still a big problem, since hundreds of families depend on this activity which in the long run brings serious problems, such as health. One case is that of the exploitation of gold in an artisanal way, this activity being rudimentary, they still apply the use of mercury, either for the separation of some material foreign to said metal, such as some type of stone, such is the case as Pyrite or some type of Sulfur. This type of separations when done in an artisanal way the worker will be exposed directly with the Mercury, inhaling the vapor of the metal in question, thus seriously affecting his health, this would not only be a problem for those who perform such activity, it would also be a serious problem for those around them, whether their family or their community. [2]

The district of Huayllay, located in the department of Pasco, is a district where mining activity has led to great problems, such is the case that the population is exposed to different particulate materials, this has made the General Directorate of Health carry out a study estimating the total of particles that are in suspension, these emissions which could be in the atmosphere. The study concluded that a total of 3737 metric tons are emitted per year, which of all this $99.8 \%$ is related to the mining activity that takes place in that district, but there is a total of all those emissions which are what we call particulate matter which is $56 \%$ of those emissions studied. This particulate matter can measure at an average of $10 \mu \mathrm{m}$ (micrometers). 


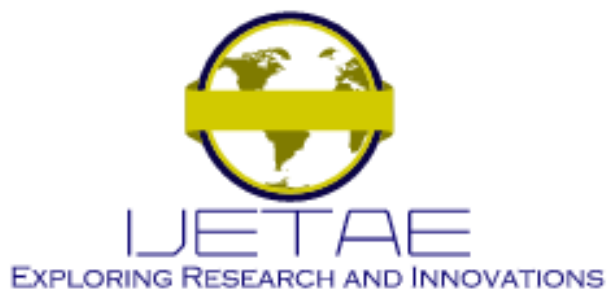

International Journal of Emerging Technology and Advanced Engineering Website: www.ijetae.com (E-ISSN 2250-2459, Scopus Indexed, ISO 9001:2008 Certified Journal, Volume 12, Issue 01, January 2022)

The other percentage of emissions are iron, copper, lead, and manganese. These emissions are even more dangerous since the mining company works in Tajo Abierto. But not only that is the problem, the deposit of mineral waste, such as tailings, seriously affect the environment generating a greater number of emissions of particulate matter which I am very serious for the population since this has a direct impact on lung diseases, according to research developed by the World Health Organization, these emissions severely affect the respiratory system. [3]

The objective to be presented in the research work is to implement a system to measure air pollution, and the parameters to be visualized in a cellular application, and these parameters compare them with the levels of other mining cities in the world, in such a way that it allows to move the already traditional equipment, which its scope of operation is restricted only to academic fields, industrial and governmental; what we intend here is that every natural person can count on the possibility of being able to monitor the contamination to which they are exposed. For the elaboration we will see the need to make an autonomous system which is capable of achieving the measurement of air quality, here we will be based on the use of sensors such as the MQ-7, which will measure $\mathrm{CO}$ emissions, and the use of the Arduino microcontroller, and the use of the Bluetooth device with which it can be visualized in a mobile application and be able to compare them with the allowed parameters of MINAM, as in [7]

The Arduino UNO, which is free software, has an open source so that anyone can make the modification and program it. Another of the components to use will be the sensors with which the microcontroller will work on this occasion we will use the sensor for particulate matter, which is the GP2Y1010AU0F Sensor, the sensor for toxic gases, which will be the MQ-2 and MQ-9, You can also count on the MQ-7 sensor which will be for $\mathrm{CO}$ emissions, and all this census data can be viewed in an Android application, for which we will have the Bluetooth device.

\section{LITERATURE REVIEW}

In [4] he indicates that the problem is the air quality in urban areas in which people are exposed, these being the main problems for the diseases that have been occurring, such as cancer, cardiovascular diseases and respiratory diseases. They proposed an implementation of electronic devices at a very low cost to be able to carry out the measurement of air quality. For the implementation of this system were carried out in 5 stages.
Identification of the variable: This is where it was seen with which variable you want to measure either humidity, temperature, or carbon monoxide $(\mathrm{CO})$. Selection of the controller and sensors: It is where it was analyzed with which controller to work, which they worked with the already classic Arduino controller, and the selection of sensors was made according to the variable to be measured. Implementation of the device: This is where the physical work on the controller is carried out, such as connecting the sensors and connecting a Bluetooth device to perform the measurements in real time on a mobile device such as the cell phone. Controller programming: It is where an algorithm will be applied to the controller in this case for the variables to which you want to measure, perform data storage, Bluetooth configuration. Adaptation to the mobile: The application to which they used was the AirCasting, which being this an open-source application. As a result, measurements were obtained having that some of them were outdated with respect to the parameters of the reference sensors, the measurements which were outdated were adjusted in the algorithm, but after six tests it could be put into phase with what it is with respect to the reference measurement. In conclusion, it was reached that this device can be used to make the measurements of the variables worked, these being $40 \%$ cheaper compared to the existing devices.

In [5] they refer to the polluting gases to which every student of the Automotive laboratory of the Salesian Polytechnic University (UPS) is exposed, this one based in Guayaquil. It was proposed to create a system for measuring polluting gases which allowed its study to be carried out. For the realization of this project, a prototype was made in which certain procedures were followed. Design of the prototype network: Here you can choose the different sensors with which you will work such as the MQ-7 (to measure carbon monoxide - CO), MG-811 (for the measurement of carbon dioxide - $\mathrm{CO} 2$ ); and the use of controllers such as the Arduino nano and the Raspberry P13. Elaboration of the prototype: It is where the different sensors will be assembled in both the Arduino and the Raspberry, this one for its connection to the network. Configuration of the sensors and the actuator: This configuration will be given according to the programming language of the controller and make the declaration of each analog input of each sensor. Analysis of the result: This is where you can detect the different types of polluting gases and through a mobile application to be able to carry out their monitoring, in this case the measurement in an enclosed space. 


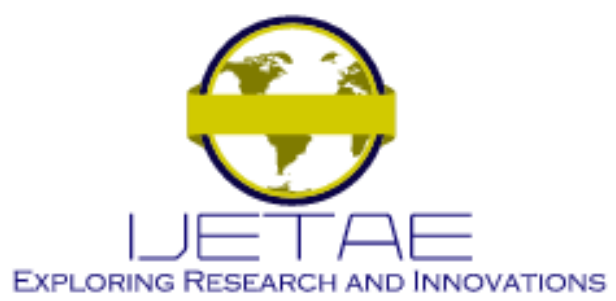

International Journal of Emerging Technology and Advanced Engineering

Website: www.ijetae.com (E-ISSN 2250-2459, Scopus Indexed, ISO 9001:2008 Certified Journal, Volume 12, Issue 01, January 2022)

As a result, it was seen that this project is very viable to be able to detect the emission of CO AND CO2 gas, all this through the application installed on the cell phone, where the user can monitor how much is the concentration of these gases, all this in the semi-closed environment. As a conclusion, being the tests in semi-enclosed spaces, the harmful ones that are harmful to health exposure to polluting gases such as $\mathrm{CO}$ were obtained, and carrying out the tests in different vehicles, it was concluded that the older these vehicles are, the greater the degree of pollution that can occur, being quite relevant the different models of vehicles, the year and the type of fuel that can be used.

In [6] they indicate that Peru being a mining country, the population where these activities are carried out are exposed to different types of metals such as Lead, Cadmium, Arsenic; and others. For this, it is proposed to carry out an autonomous mobile system, which can measure the level of pollution that may be occurring, and these parameters can be compared with those determined by the Ministry of the Environment (MINAM). The methodology which was used was as follows. Requirement: first, it was possible to know the parameters to which it had to be sensed, these parameters could be given based on polluting gases such as Sulfur Dioxide, Carbon Monoxide, among others; a list of requirements was drawn up to which the autonomous mobile system should meet. Blackbox: here it will be presented what will be the inputs and outputs of this entire autonomous system. Functions: the system will have a very specific task within which the most outstanding thing will be to make the measurement and make an information of the parameters that can be measured. As a result, we will have that being an autonomous system will not depend on man so that he can make the measurements of the desired parameters, taking these parameters to the Cloud platform, and thus be able to compare them with the parameters of the MINAM. In conclusion, it was possible to verify that the combination of mechanical devices and similar systems, the autonomous system could be able to perform the measurement of pollutants in the air as in the ground, and even more so using the architecture of the software the ADD 3.0 methodology was used thus having the quality, restrictions that could worry some current architectures.

\section{METHODOLOGY}

In Figure 1. We will have the flowchart model of the system to measure air pollution in the district of Huayllay.

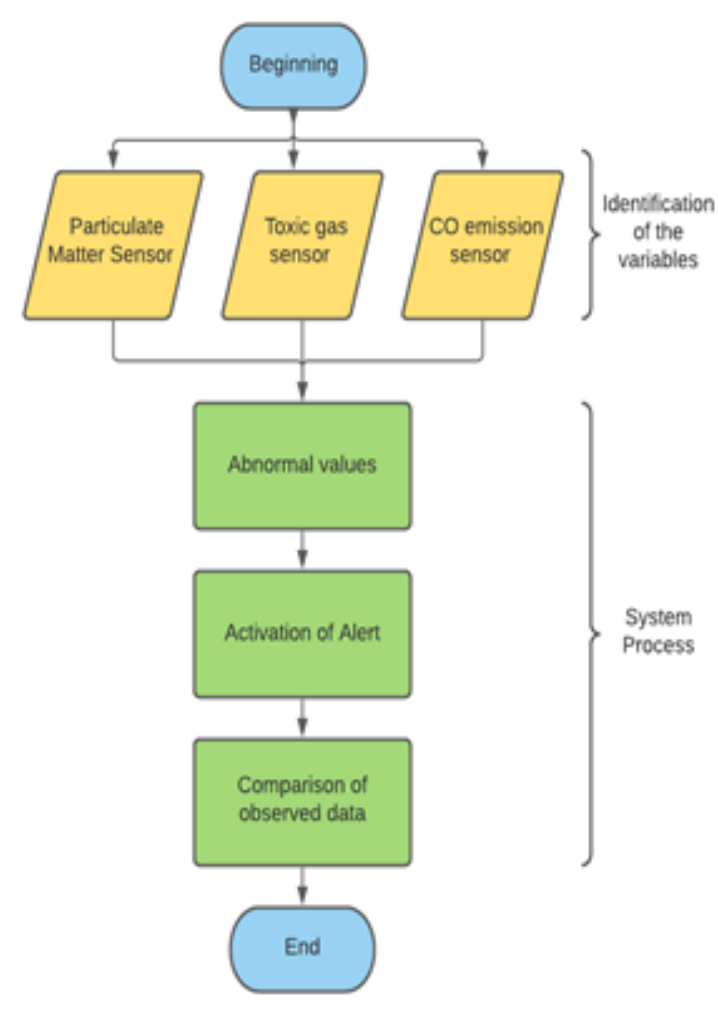

Fig. 1. Flowchart of the system to measure air pollution.

\section{A. Identification of variables.}

Understanding that what must be measured is air pollution, three types of variables to be measured were established, which are: particulate matter, toxic gases, and carbon monoxide, for which we will describe each of them.

\section{- Particulate Matter Sensor.}

GP2Y1010AU0F is a sensor for the detection of particulate matter (dust) by optical detection system. With the application of the pulse output system, the device can even identify dust from a single dwelling. You can differentiate house dust and cigarette smoke. The sensor makes it possible to easily measure the concentration of dust in the air. This sensor is composed of an infrared diode and a phototransistor in a diagonal arrangement, which allow measuring the light reflected by dust particles in the air. The sensor has an analog output of linear voltage and proportional to the proportion of dust detected $(\mathrm{mg} / \mathrm{m} 3$ dust density). The sensor sensitivity is $0.5 \mathrm{~V}$ per $0.1 \mathrm{mg}$ of powder per cubic meter [8]. 


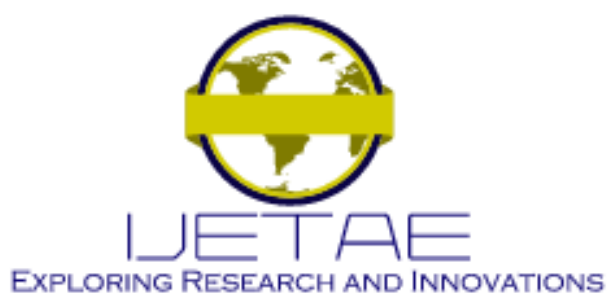

International Journal of Emerging Technology and Advanced Engineering

Website: www.ijetae.com (E-ISSN 2250-2459, Scopus Indexed, ISO 9001:2008 Certified Journal, Volume 12, Issue 01, January 2022)

The characteristics of this sensor will be shown in Table I.

TABLE I.

FEATURES OF THE GP2Y1010AU0F.

\begin{tabular}{|l|l|}
\hline \multicolumn{1}{|c|}{ PARAMETERS } & \multicolumn{1}{|c|}{$\begin{array}{c}\text { MEASUREMENT } \\
\text { RANGE }\end{array}$} \\
\hline Continuous voltage & $-0.3 \mathrm{Vdc}$ up to $7.0 \mathrm{Vdc}$ \\
\hline Stream density & $11 \mathrm{~mA}$, maximum $20 \mathrm{~mA}$ \\
\hline $\begin{array}{l}\text { Dust } / \mathrm{m} 3 \text { Microgram per } \\
\text { detection range } \\
\text { cubic meter) }\end{array}$ \\
\hline Sensitivity & $0.5 \mathrm{Vdc} /(0.1 \mathrm{mg} / \mathrm{m} 3)$ \\
\hline $\begin{array}{l}\text { Operating } \\
\text { temperature }\end{array}$ & $-10^{\circ} \mathrm{C}$ to $65^{\circ} \mathrm{C}$ \\
\hline $\begin{array}{l}\text { Detects the diameter } \\
\text { of the particle }\end{array}$ & $>1 \mathrm{um}$ \\
\hline Dimensions & $46 \times 30 \mathrm{x} 17.6(\mathrm{~mm})$ \\
\hline Weight & 16 grams \\
\hline
\end{tabular}

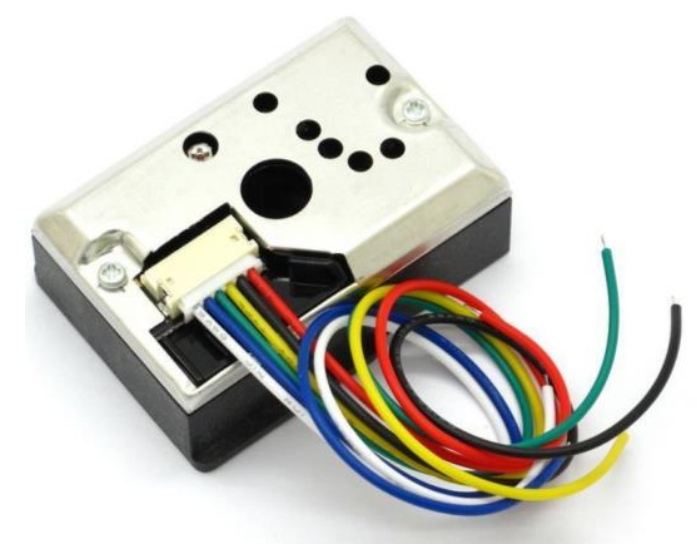

Fig. 2. Sensor GP2Y1010AU0F.

\section{- Toxic Gas Sensor.}

This sensor model is very sensitive regarding LPG, Propane and Hydrogen. Within its use it can also be applied in the detection of gas and smoke from fuels, and especially to domestic gas. It is of the semiconductor type, which has an encapsulation inside a black Bakelite, this transducer is the MQ-2 Gas Sensor as shown in Figure 3. It is a very low price device which has multiple applications. [9]
The characteristics of the sensor will be detailed in table II.

TABLE II.

FEATURES OF THE MQ-2

\begin{tabular}{|l|l|}
\hline PARAMETERS & $\begin{array}{l}\text { MEASUREMENT } \\
\text { RANGE }\end{array}$ \\
\hline Voltage & $5 \mathrm{Vdc}$ \\
\hline Power & $\leq 900 \mathrm{~mW}$ \\
\hline Sensitivity & $\begin{array}{l}300 \sim 10000 \mathrm{ppm} \\
\text { (parts per million) }\end{array}$ \\
\hline Temperature & $20^{\circ} \mathrm{C}$ \\
\hline Humidity & $65 \%$ \\
\hline
\end{tabular}

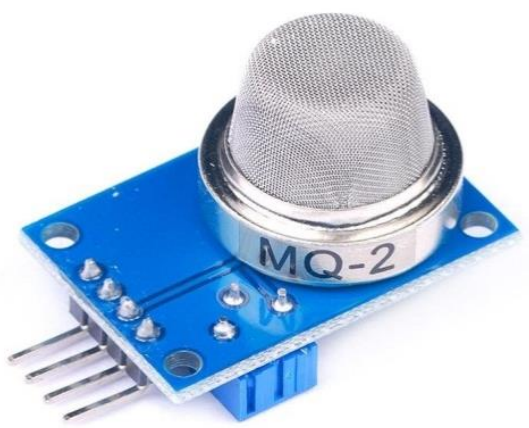

Fig. 3. Sensor de Gas MQ-2

\section{- CO Emissions Sensor.}

The sensor with which we will work is the MQ-7 as shown in figure 4, with which it is possible to measure Carbon Monoxide (CO) gas, this sensor is ideal for identifying harmful concentrations of $\mathrm{CO}$ in the air and thus evade their health problems. This sensor can identify concentrations in the range of 20 to 2000ppm (parts per million). The module has an analog output that comes from the voltage divider that forms the sensor and a load resistance, it also has a digital output adjustable by a potentiometer, this output has an indicator LED [10].

The technical characteristics of the sensor will be detailed in Table III. 


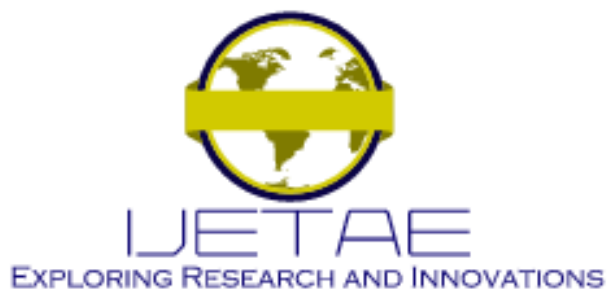

International Journal of Emerging Technology and Advanced Engineering

Website: www.ijetae.com (E-ISSN 2250-2459, Scopus Indexed, ISO 9001:2008 Certified Journal, Volume 12, Issue 01, January 2022)

TABLE III.

Features OF CCS811.

\begin{tabular}{|l|c|}
\hline \multicolumn{1}{|c|}{ PARAMETERS } & $\begin{array}{c}\text { MEASUREMENT } \\
\text { RANGE }\end{array}$ \\
\hline Voltage & $5.0 \mathrm{Vdc}$ \\
\hline Heating voltage & $\begin{array}{c}5.0 \mathrm{Vdc} \text { (high) } \\
1.4 \mathrm{Vdc} \text { (low) }\end{array}$ \\
\hline Heating resistance & $33 \mathrm{ohms}$ \\
\hline Resistance power & $350 \mathrm{~mW}$ \\
\hline $\begin{array}{l}\text { Working } \\
\text { temperature }\end{array}$ & $-20^{\circ} \mathrm{C}$ to $50^{\circ} \mathrm{C}$ \\
\hline $\begin{array}{l}\text { Humidity } \\
\text { Less than } 95 \%\end{array}$ \\
\hline $\begin{array}{l}\text { Oxygen } \\
\text { concentration }\end{array}$ & $21 \%$ \\
\hline
\end{tabular}

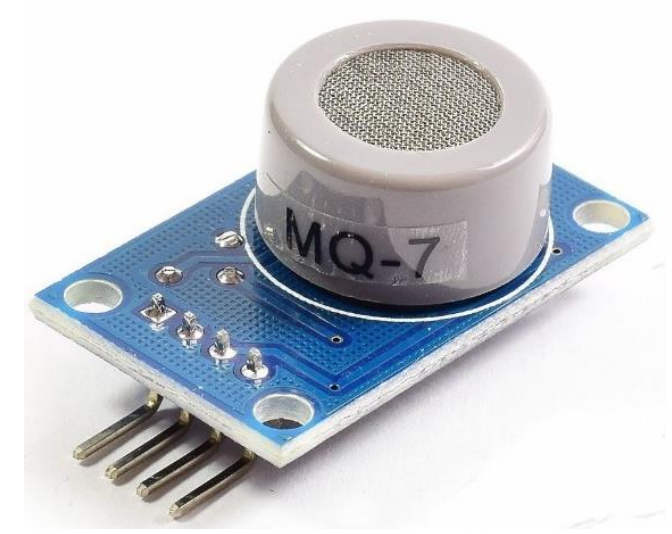

Fig. 4. MQ-7 sensor.

\section{B. System process.}

To develop the optimal detection of each of the parameters that will be measured, we will develop the following processes.

\section{Abnormal Values.}

Each sensor has a different way of converting the physical variable into an electronic variable, this electronic variable is the one we will work on, for which we will review how each of these sensors will detect.

\subsection{Particulate Matter Sensor Operation.}

In [11] we can interpret that this Particulate Matter sensor "GP2Y1010AU0F" is a device to identify house particulate matter, cigarette smoke, etc. and designed as a sensor for the automatic performance of applications such as air purifier and air conditioner with air purifier functionality.

- The light from the light emitter (light-emitting diode) is stained with a lens and a slit as shown in Figure 5. In addition, for the light detector (photodiode), a lens and a slit are placed before it to crop the disturbing light and identify the reflection of the light (by identifying the particulate matter) efficiently. The sector where those 2 optical axes intersect is the detection zone of the device.

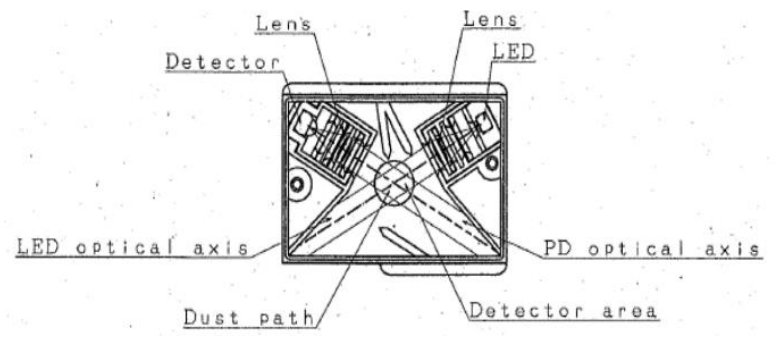

Fig. 5. Detection of particulate matter.

- Figure 6 shows what happens inside the device once there is no particulate matter and Figure 7 shows what happens once there is particulate matter. The device produces a voltage output even once no particulate matter is detected. This output voltage without particulate matter is specified as $0 \mathrm{Vdc}$ (continuous voltage) in the description. This is because the light emitted by the LED reflects about the device and a section reaches the detector.

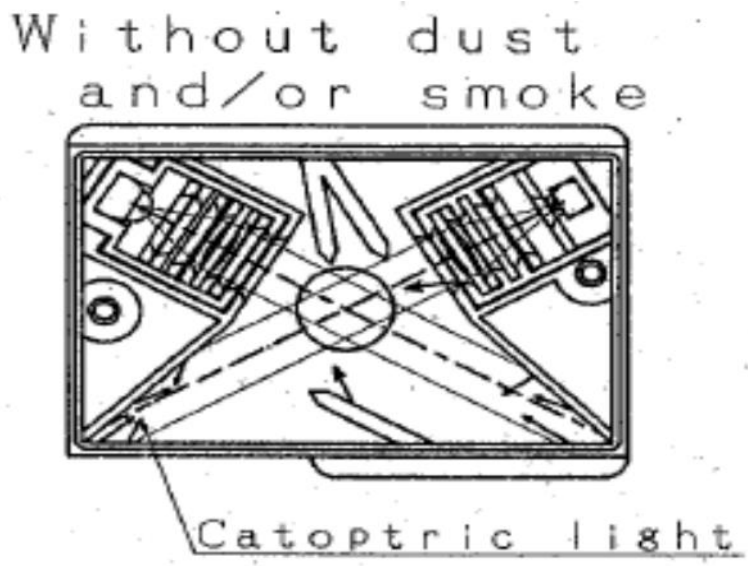

Fig. 6. Detection without particulate matter. 


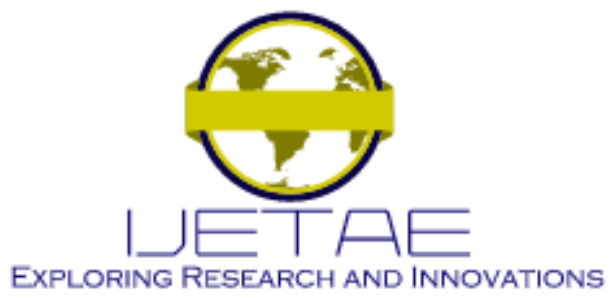

International Journal of Emerging Technology and Advanced Engineering

Website: www.ijetae.com (E-ISSN 2250-2459, Scopus Indexed, ISO 9001:2008 Certified Journal, Volume 12, Issue 01, January 2022)

- Figure 7 shows how the device works once there is particulate matter and/or cigarette smoke inside. In this situation, the detector detects light reflected by dust and/or a particle from cigarette smoke. The current in proportion to the proportion of light detected leaves the detector and the device produces an analog voltage output (pulse output) after the amplifier circuit amplifies the detector current.

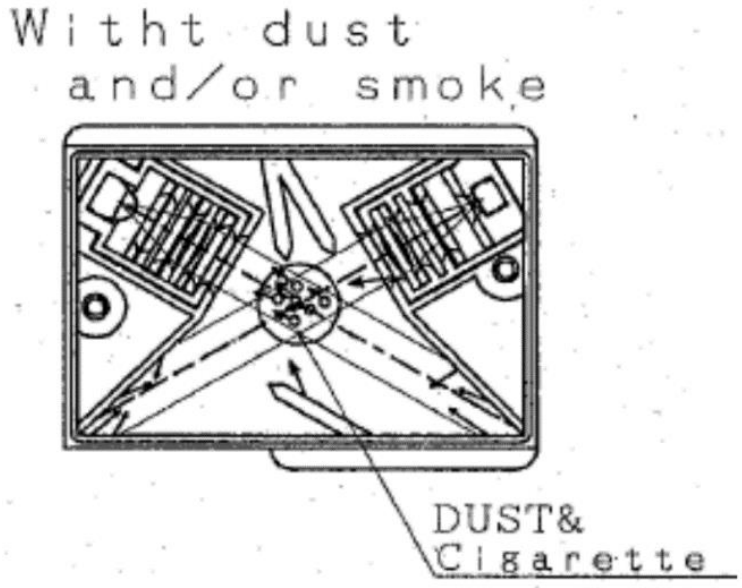

Fig. 7. Detection of particulate matter.

\subsection{Toxic Gas Sensor Operation.}

In [9] you will show us that the sensor, needs 2 voltage inputs; heater voltage ( $\mathrm{VH}$ ) and circuit voltage (VC), $\mathrm{VH}$ is used to provide standard working temperature to the sensor and can adopt DC or AC, meanwhile VRL is the voltage of the RL load resistance that is in series with the sensor, $\mathrm{Vc}$ supplies the sensing voltage to the RL load resistor and must adopt direct current, as shown in Figure 8.

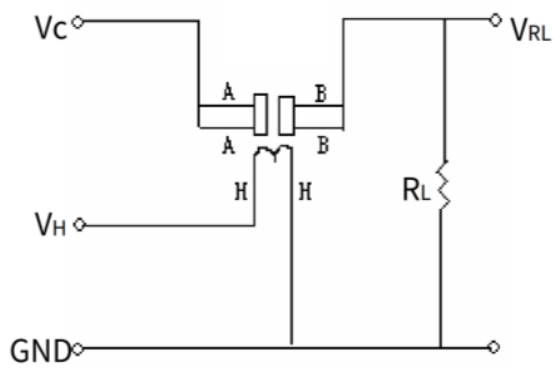

Fig. 8. Electrical diagram of the MQ-2.
Once the flammable gas exists, which is the working target of the sensor, the conductivity of the sensor increases along with the growth of the gas concentration. In this work we will take advantage of the possibility of transforming the change of conductivity so that it corresponds to the output signal of the gas concentration by means of a circuit.

\subsection{Operation CO Emissions Sensor.}

En [12] will show us that the sensitive material of the MQ7 gas sensor is $\mathrm{SnO} 2$, which has lower conductivity in clean air. It executes the detection by means of the high and low temperature period procedure, and detects $\mathrm{CO}$ once the temperature is low (heated by $1.4 \mathrm{~V}$ ) as shown in Figure 9. The conductivity of the sensor is higher along with the growth of the gas concentration. Once the temperature is high (heated by $5.0 \mathrm{~V}$ ), it cleans the other adsorbed gases at low temperature. Use a simple electrocircuit, convert the conductivity change to correspond to the output signal of the gas concentration. Once the sensor changes from clean air to carbon monoxide ( $\mathrm{CO}$ ), the measurement of the output signal is done in one or 2 whole heating periods $(2.5$ min of high voltage at low voltage). Its effective history can achieve 5 years in conditions of use

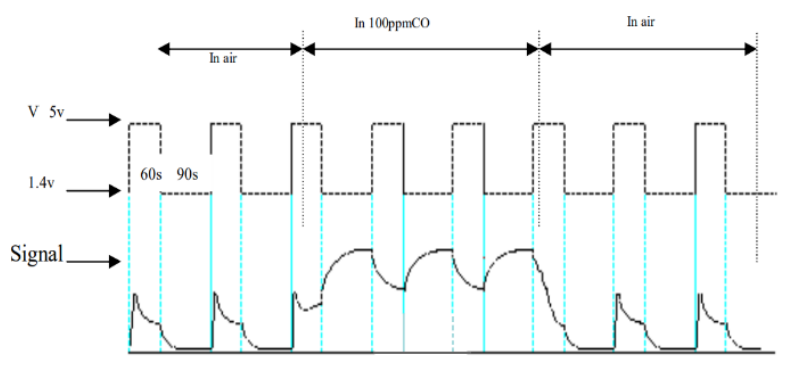

Fig. 9. Operation of the $\mathrm{CO}$ emissions sensor.

\section{Activation of Alert.}

Knowing how each sensor converts a physical variable into an electronic variable, in this part we will see how each sensor will be activated and what are the ranges for the activation of each of them.

\subsection{Activation of the Particulate Matter Sensor.}

- It is necessary a resistor, R1 $=150 \mathrm{ohms}$ and a capacitor, $\mathrm{C} 1=220$ microfarads all this for the operation of the LED of the particulate matter sensor, without the two components already mentioned, the device will not work. 


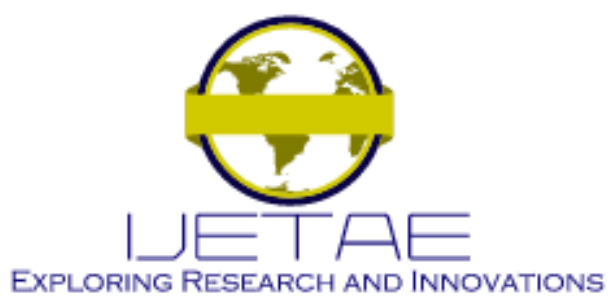

International Journal of Emerging Technology and Advanced Engineering

Website: www.ijetae.com (E-ISSN 2250-2459, Scopus Indexed, ISO 9001:2008 Certified Journal, Volume 12, Issue 01, January 2022)

- As conditions of entry of the LED terminal, the LED drive conditions mentioned in table IV of electro-optical properties of the description shall apply. Once the LED is activated in conditions that exceed specifications, the properties of the device will be damaged.

TABLE IV.

FEATURES OF CCS811.

\begin{tabular}{|l|l|l|l|l|}
\hline $\begin{array}{l}\text { Param } \\
\text { eter }\end{array}$ & $\begin{array}{l}\text { Sym } \\
\text { bol }\end{array}$ & $\begin{array}{l}\text { Specif } \\
\text { ied } \\
\text { condit } \\
\text { ion }\end{array}$ & $\begin{array}{l}\text { Recomme } \\
\text { nded } \\
\text { condition }\end{array}$ & unit \\
\hline $\begin{array}{l}\text { Pulse } \\
\text { cycle }\end{array}$ & $\mathrm{T}$ & 10 & $10 \pm 1$ & $\begin{array}{l}\text { ms(millise } \\
\text { cond) }\end{array}$ \\
\hline $\begin{array}{l}\text { Pulse } \\
\text { width }\end{array}$ & $\mathrm{Pw}$ & 0.32 & $0.32 \pm .02$ & $\begin{array}{l}\text { ms(millise } \\
\text { cond) }\end{array}$ \\
\hline
\end{tabular}

- The LED emits pulsed light. The detected signal is amplified by the amplifier circuit and turned off as the output synchronized with the LED pulse task.

- As shown in Figure 10, the detailed output estimate is the one measured $0.28 \mathrm{~ms}$ after the LED is turned on. Therefore, it is offered that the microcomputer reads the output $0.28 \mathrm{~ms}$ after the emission of the LED.

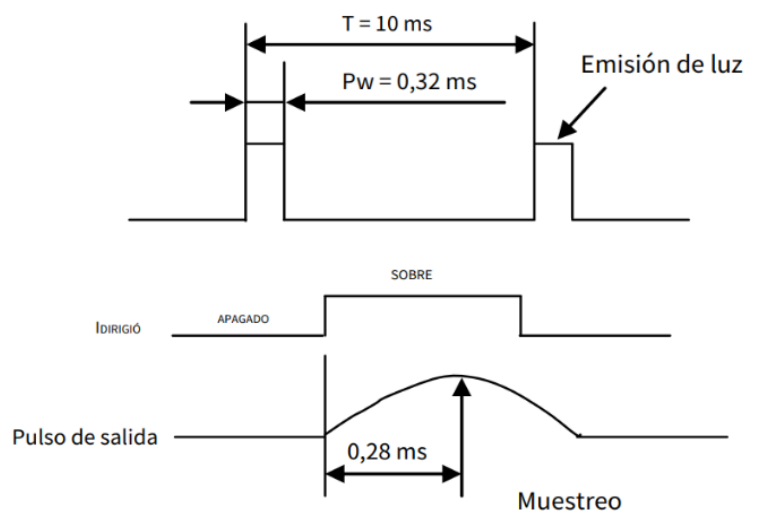

Fig. 10. Sampling time of the output pulse.

- The time required for the device to be ready to identify dust from the time the system is turned on is less than 1 second.

\subsection{Activation of the Toxic Gas Sensor.}

The sensitive material of the MQ2 gas sensor is $\mathrm{SnO} 2$ (tin dioxide), which has lower conductivity in clean air.
Once the target fuel gas is present, the conductivity of the sensor is higher along with the increasing gas concentration. Using a simple electrical circuit, it converts the conductivity change to correspond to the output signal of the gas concentration. [9]. With this Gas sensor we have the possibility of knowing if the air is clean or independent of gases, due to the high conductivity shown by the device in these conditions and while detecting gas concentration, it reduces that conductivity. Therefore, conductivity is related to the concentration of gases in the environment, this sensor can measure concentrations of natural gas in the air because it can identify concentrations from 300 to 10000 ppm and provides an analog output that comes out of the voltage divider and a load resistance, in addition which is good to identify gas leaks in a home or industry, as shown in Figure 11.

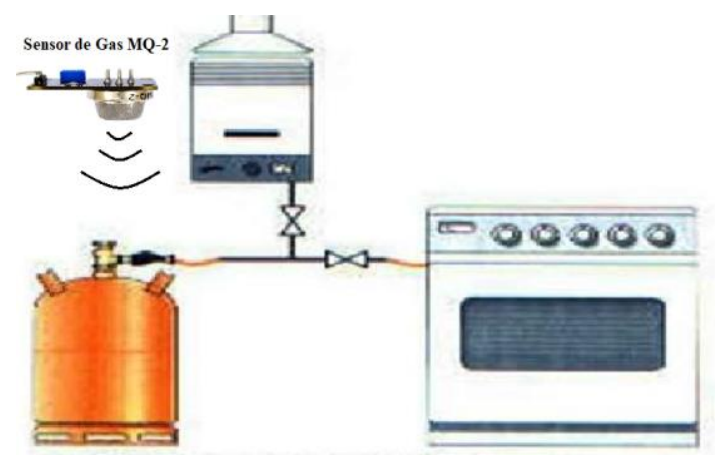

Fig. 11. Identifying gas leakage in the kitchen of a home.

\subsection{Activation of the CO Emissions Sensor.}

The $\mathrm{CO}$ emissions sensor is a sensor for the detection of carbon monoxide $(\mathrm{CO})$ to measure the concentration of this gas in the air. The $\mathrm{CO}$ emissions sensor can measure monoxide gas concentrations between 20 to $2000 \mathrm{ppm}$ (parts per million). This sensor has a high sensitivity and a fast response time, which is quite simple to interface the sensor with a microcontroller, because we have the possibility of using an analog input pin to measure the concentration of the gas. The connections that the sensor needs are very simple only needs food intake of $5 \mathrm{~V}$ for the heating component. Figure 12 shows the typical sensitivity properties of the $\mathrm{CO}$ emission sensor for various gases. in its: Temperature: $20^{\circ} \mathrm{C}$, Humidity: $65 \%, \mathrm{O} 2$ concentration $21 \%, \mathrm{RL}=10 \mathrm{k} \Omega$.

Ro: sensor resistance at $100 \mathrm{ppm}, \mathrm{CO}$ in clean air. Rs: resistance of the sensor in various gas concentrations. 


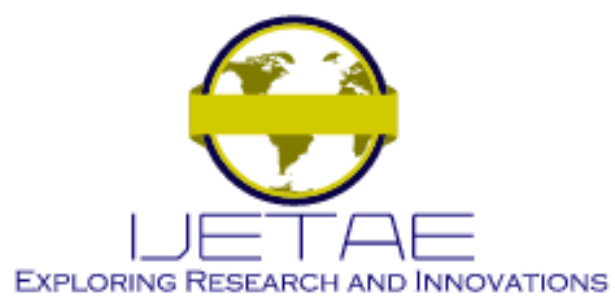

International Journal of Emerging Technology and Advanced Engineering

Website: www.ijetae.com (E-ISSN 2250-2459, Scopus Indexed, ISO 9001:2008 Certified Journal, Volume 12, Issue 01, January 2022)

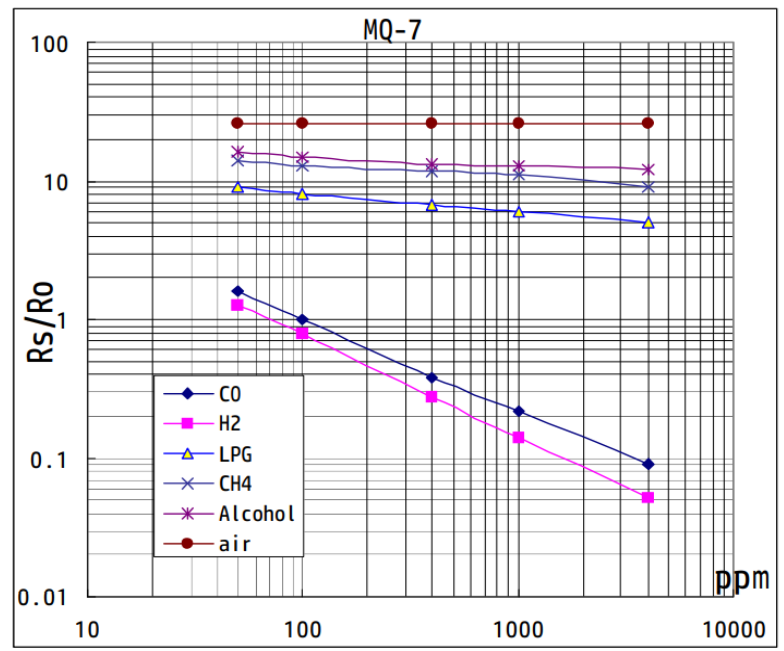

Fig. 12. Characteristic curve of the sensitivity of the $\mathrm{CO}$ emission sensor.

In figure 15, the virtual installation of the three sensors already mentioned above, all these in the Arduino Uno, and for later visualization and control on the cell phone we will have a Bluetooth module.

In figure 13, it is shown how the physical connection of the different sensors will be, for this we make the use of the Proteus program, to develop simulations prior to physical work.

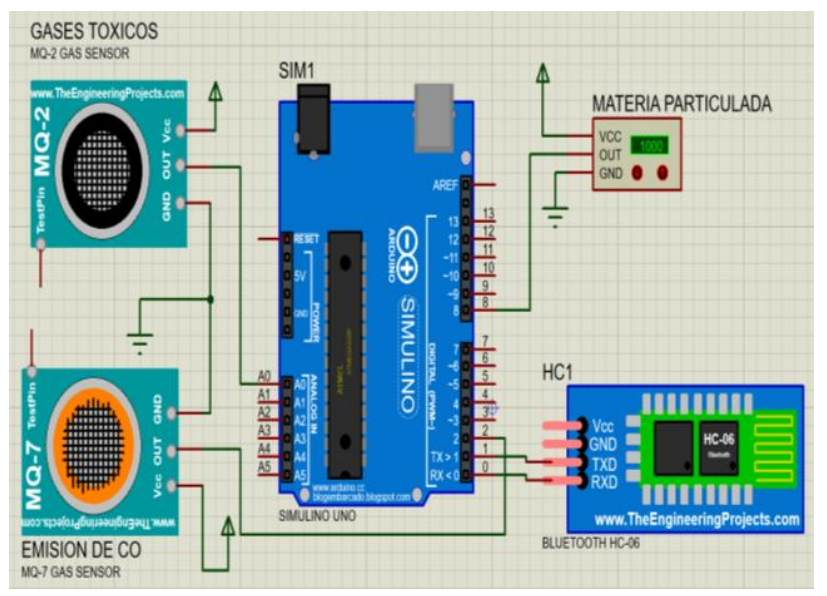

Fig. 13. Connection of the sensors in the Arduino.

\section{RESULTS}

In this section we will first perform the test separately of each of the sensors, for this we will use our protoboard, cables for the connection and each of the respective sensors.

\section{- Particulate Matter Sensor.}

In figure 14, you can see the physical connection, of the particulate matter sensor, for which we used the Arduino microcontroller, a Bluetooth module and an LCD display, and for its programming we based on an equation declared in [13] where here we could make the measurement of the density of the air the unit with which we worked were ug/ $\mathrm{m} 3$.

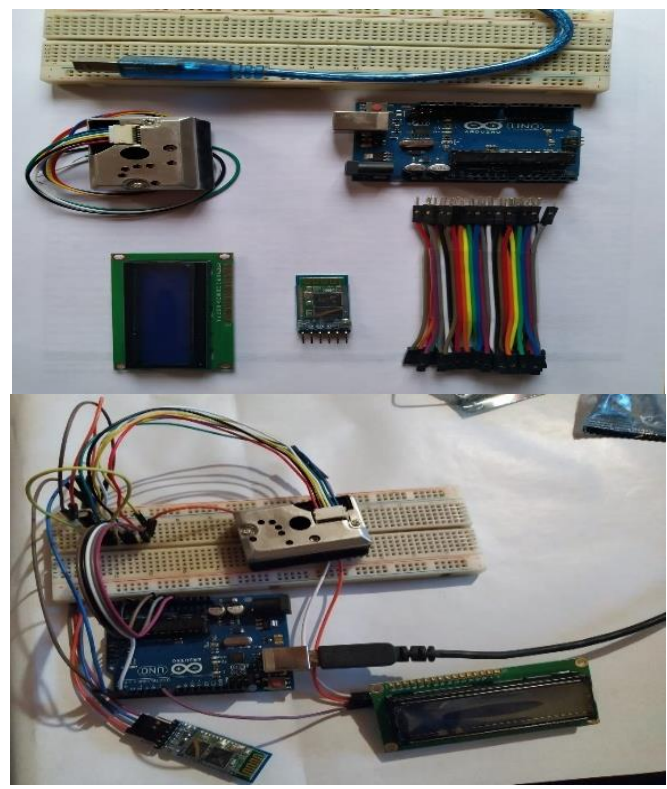

Fig. 14. Connection of the particulate matter sensor.

\section{- Toxic Gas Sensor.}

In the same way the connection of the toxic gas sensor was made, all this with the Arduino microcontroller, a Bluetooth module, as shown in figure 15. What is intended is to visualize both normal and abnormal parameters on a mobile device, such as a cell phone or table. 


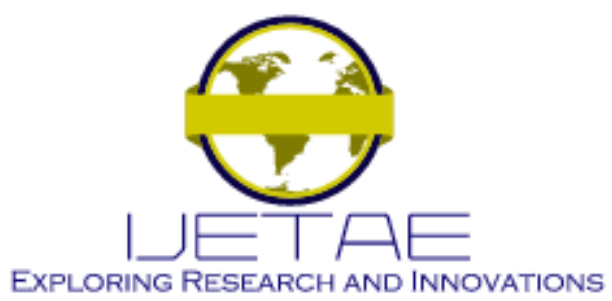

International Journal of Emerging Technology and Advanced Engineering

Website: www.ijetae.com (E-ISSN 2250-2459, Scopus Indexed, ISO 9001:2008 Certified Journal, Volume 12, Issue 01, January 2022)

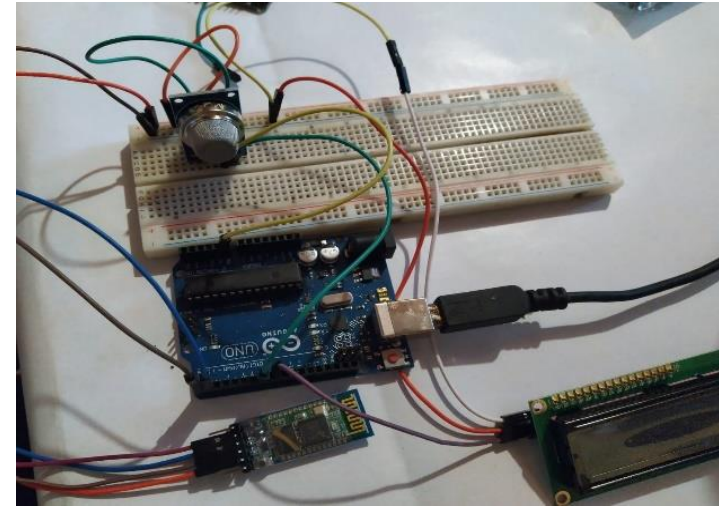

Fig. 15. Electrical connection of the Toxic Gas sensor.

\section{- CO Emission Sensor.}

In the same way the physical connection was made in the Arduino microcontroller, for which we have the help of a protoboard, connection cables and for the previous visualization of the parameters to be measured there was an LCD display, as shown in figure 16 . But the reading of these parameters can be read on a mobile device for comparison of levels with other places where $\mathrm{CO}$ emissions can originate, as well as being able to review the measurements in real time all this through the Bluetooth module [14].

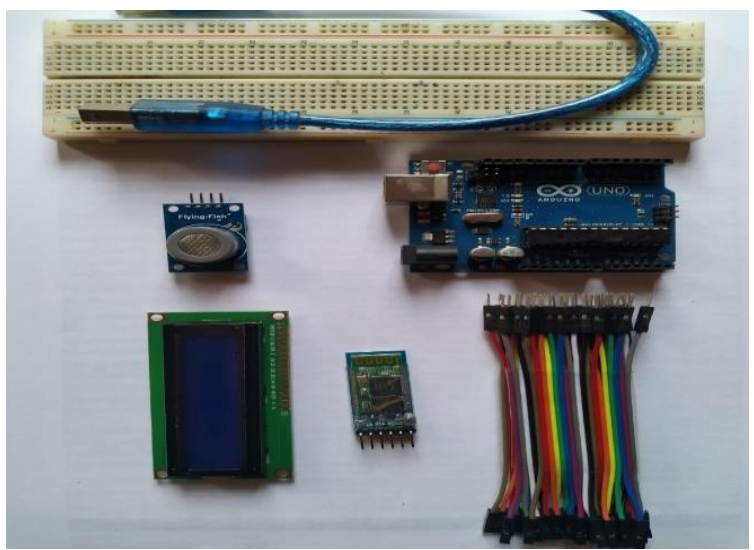

Fig. 16. Materials to be used for the connection of the $\mathrm{CO}$ emissions sensor.

When the sensors detect normal values these will be displayed on the LCD screen, as shown in Figure 16.

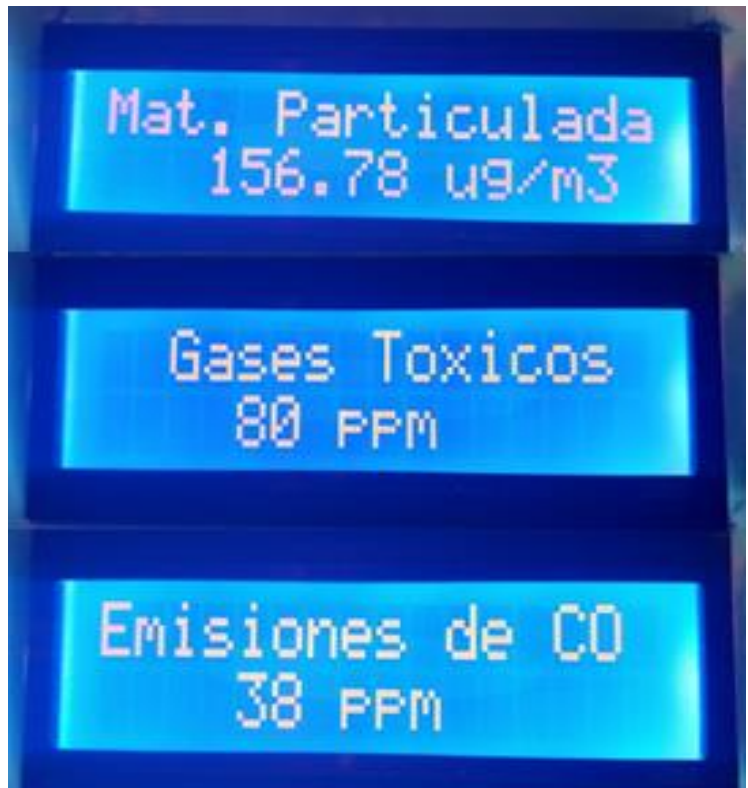

Fig. 17. Normal values of the sensors.

As shown the values are within the standard parameters of the ambient air quality.

In the same way when the sensors detect abnormal values these will be shown on the LCD screen, as shown in Figure 17.

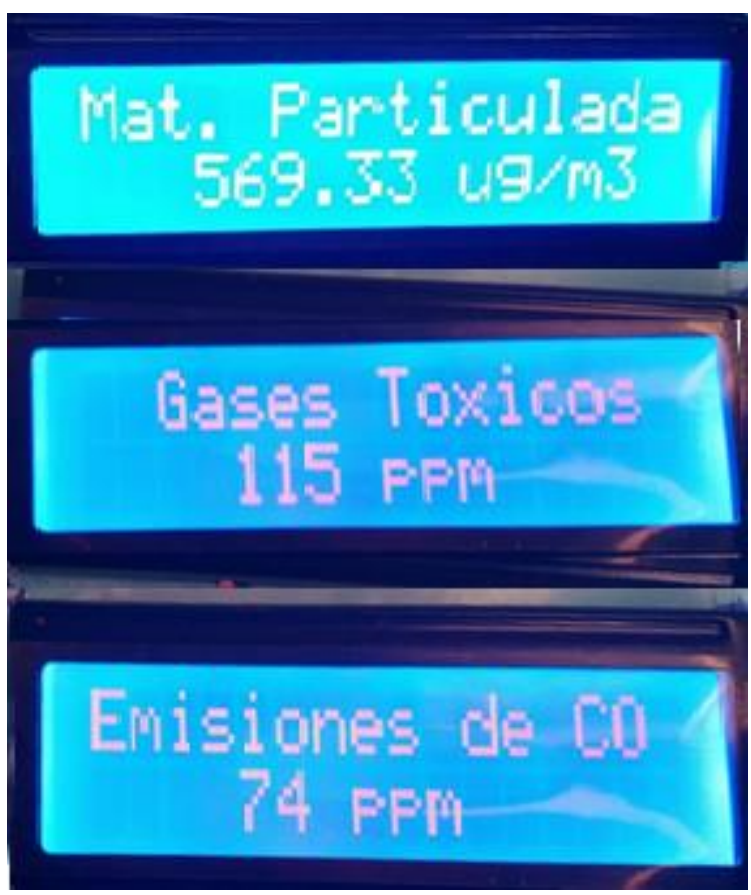

Fig. 18. Abnormal sensor values 


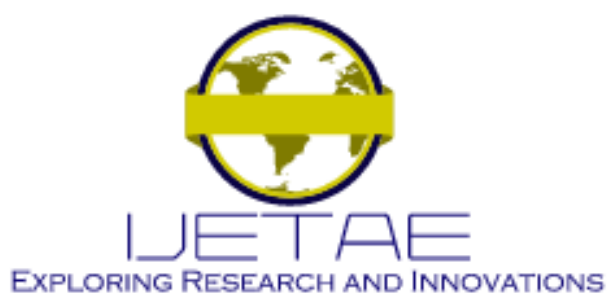

International Journal of Emerging Technology and Advanced Engineering

Website: www.ijetae.com (E-ISSN 2250-2459, Scopus Indexed, ISO 9001:2008 Certified Journal, Volume 12, Issue 01, January 2022)

As shown the values detected abnormal presence in the environment, therefore, we will have a visual alert on the LCD screen, as shown in Figure 18.

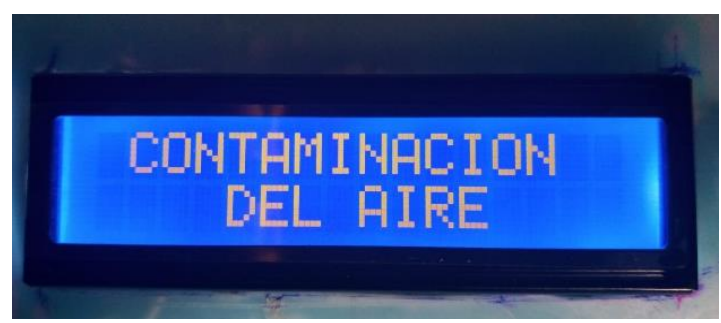

Fig. 19. Air pollution alert message.

With the data obtained, the following table $\mathrm{V}$ was made, this for normal environmental conditions.

TABLE V.

MEASUREMENTS OF VARIABLES IN NORMAL ENVIRONMENT.

\begin{tabular}{|c|c|c|}
\hline \multirow{2}{*}{ Variables } & \multicolumn{2}{|c|}{ Normal } \\
\cline { 2 - 3 } & $\begin{array}{c}\text { Free } \\
\text { environment }\end{array}$ & $\begin{array}{c}\text { Enclosed } \\
\text { environment }\end{array}$ \\
\hline $\begin{array}{c}\text { Particulate } \\
\text { matter }\end{array}$ & $160.94 \mathrm{ug} / \mathrm{m} 3$ & $241.45 \mathrm{ug} / \mathrm{m} 3$ \\
\hline Toxic gases & $76 \mathrm{ppm}$ & $78 \mathrm{ppm}$ \\
\hline CO emissions & $37 \mathrm{ppm}$ & $41 \mathrm{ppm}$ \\
\hline
\end{tabular}

In the same way Table VI was developed, but this already for abnormal environmental conditions.

TABLE VI.

MEASUREMENT OF VARIABLES IN ABNORMAL ENVIRONMENT.

\begin{tabular}{|c|c|c|}
\hline \multirow{2}{*}{ Variables } & \multicolumn{2}{|c|}{ Abnormal } \\
\cline { 2 - 3 } & $\begin{array}{c}\text { Free } \\
\text { environment }\end{array}$ & $\begin{array}{c}\text { Enclosed } \\
\text { environment }\end{array}$ \\
\hline $\begin{array}{c}\text { Particulate } \\
\text { matter }\end{array}$ & $258.05 \mathrm{ug} / \mathrm{m} 3$ & $569.33 \mathrm{ug} / \mathrm{m} 3$ \\
\hline Toxic gases & $84 \mathrm{ppm}$ & $115 \mathrm{ppm}$ \\
\hline CO emissions & $56 \mathrm{ppm}$ & $74 \mathrm{ppm}$ \\
\hline
\end{tabular}




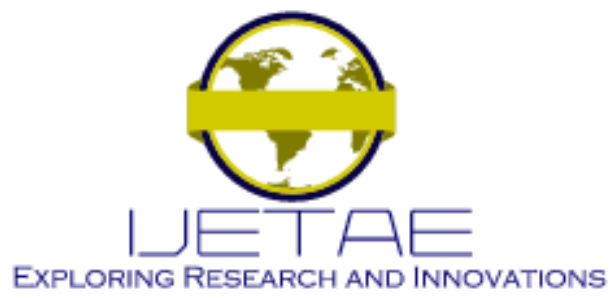

International Journal of Emerging Technology and Advanced Engineering

Website: www.ijetae.com (E-ISSN 2250-2459, Scopus Indexed, ISO 9001:2008 Certified Journal, Volume 12, Issue 01, January 2022)

In the same way, the test for the activation of the carbon monoxide emissions sensor was carried out, for this we proceeded to measure in the first 200 seconds a normal activity, then proceeded to perform the sensor test with the burning of flammable materials such as firewood, fearing if the measurement shown in Figure 21.

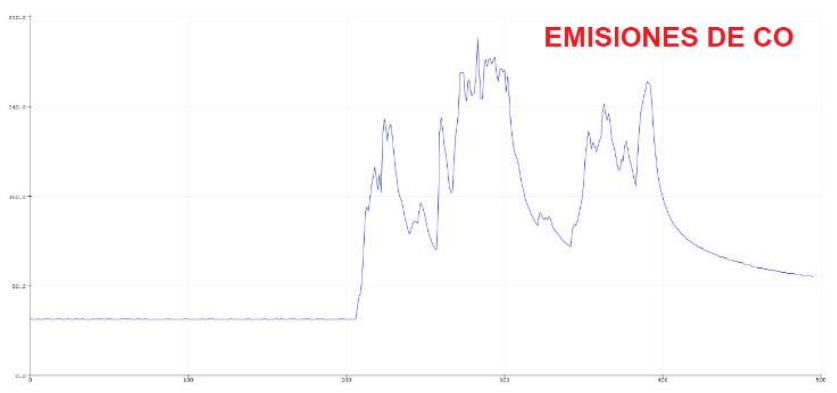

Fig. 22. Graphic reading of the CO Emission sensor.

\section{Android Application}

For the connection and visualization of the measurement parameters by means of a cell phone, an Android application was used, through which analog parameters of the measurement of the sensors can be displayed, the result is shown in Figure 22.

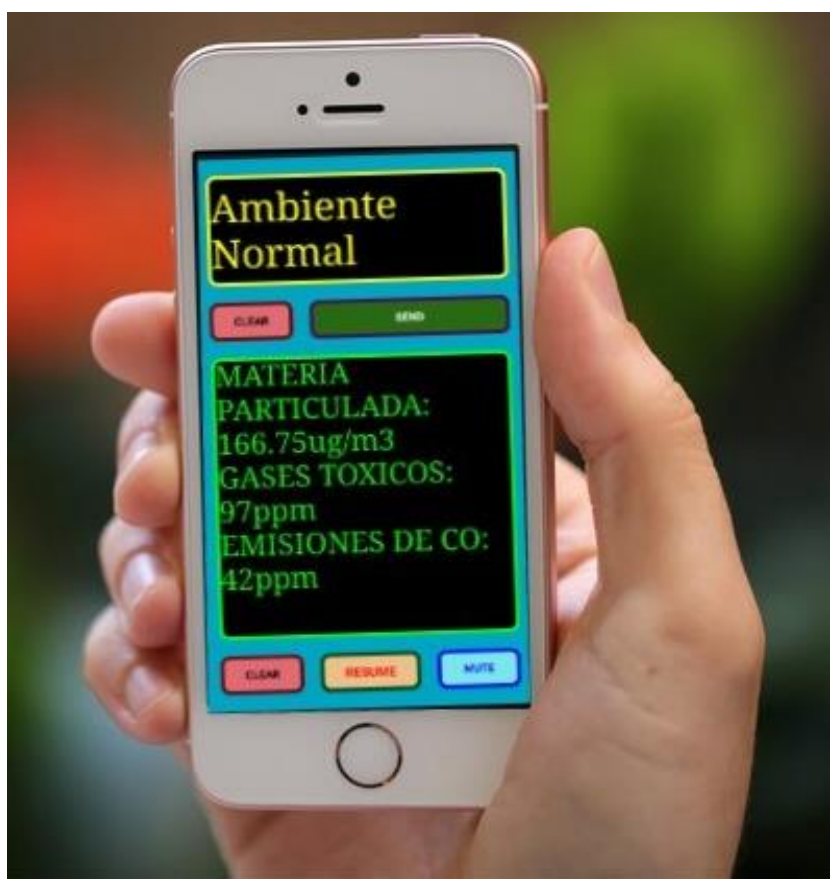

Fig. 23. Reading the parameters in an Android application.
According to [15] living in a polluted environment or would bring serious consequences for our health, since being exposed to these for a long time would lead to respiratory diseases and even cardiovascular diseases, since being exposed to particulate matter less than 2.5 micrometers (PM2.5), less than 10 micrometers (PM10) and toxic gases, would bring even fatal consequences for the human being. But if we lived in a healthy environment free of all these pollutants, it would improve our health and mood in a remarkable way, since living in a pure environment is a right of every human being.

\section{DISCUSSIONS}

In the results we could observe the work optimally of each of the sensors without the need to calibrate them, very contrary to the work in was needed for the calibration of each of the sensors, the use of humidity and temperature sensors used in this reference work was left aside, since these are not considered essential for the detection of air pollution in the mining area where we carry out the research work.

As in the work in [5] we used Mr. MQ7 for the measurement of $\mathrm{CO}$, the tests they carried out in said reference work did so with cars of different denominations, quite the contrary the work we did the test of said sensor with the burning of firewood, assuming that the vast majority of the inhabitants of the district of Huayllay use firewood and / or clods of earth for the ignition of the bonfires where food was prepared, but what caught our attention is that the $\mathrm{CO}$ emission values in a car were between $250 \mathrm{ppm}$ to $400 \mathrm{ppm}$, very different from the smoke caused by the burning of firewood, where we had measurements of between 50ppm to 74ppm.

The sensors with which we worked yielded parameters that are in an acceptable average as determined by the Ministry of the Environment, as well as in [6] where to determine these parameters to perform air quality tests, even more the use of an autonomous system where the equipment will provide periodic information on the air level, just as our equipment does not need the person to be manipulating it, only a mobile phone is enough to be able to appreciate the parameters of the air quality level. 


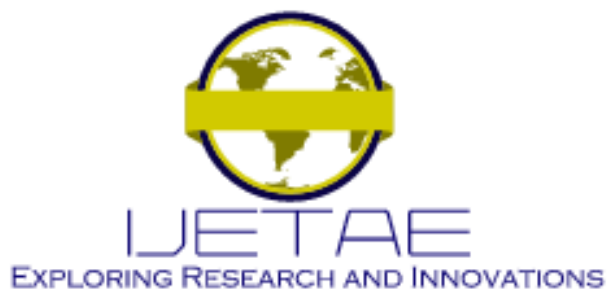

International Journal of Emerging Technology and Advanced Engineering Website: www.ijetae.com (E-ISSN 2250-2459, Scopus Indexed, ISO 9001:2008 Certified Journal, Volume 12, Issue 01, January 2022)

Nowadays air monitoring equipment is restricted only to government entities or the educational field, leaving aside ordinary people, these being the ones affected in case the air where they reside is contaminated, the work done has the same functionality as these equipment, but not as sensitive and accurate as these monitoring equipment could be in [16], but with this system we can know how good the air quality is where we reside.

\section{CONCLUSIONS}

Performing the test to each of the sensors and considering what is the sensitivity range of each of them, it was possible to appreciate that the response time to each variable that was detected, is slow; but effective, thus having basic sensors for the desired work.

The environment where the tests were carried out were closed environments where dust was circulated for the particulate matter sensor test, and cigarette smoke was used for the $\mathrm{CO}$ emission sensors, and finally for the toxic gas detector test a lighter was used where the discharge of this was made.

What is planned later is to have sensors with greater sensitivity and precision, of course these will entail a greater cost, but let's think that our health is at stake, since we need to live in a healthy and optimal environment.

During the planned work we planned to use another sensor for the detection of particulate matter, but as this is not very commercial, we could not count on it physically, but we corrected it using another with the same characteristics of this having to achieve our purpose.

\section{REFERENCES}

[1] G.C. Calderóna, "By Mining Activity in the Colombian Os Problemas Socio-Ambientais," pp. 367-379, 2017.

[2] E. Ccolqque, "Mining Contamination in the South-Middle Area of Peru by Small-Scale Gold Mining," Articul. Univ. , pp. 1-67, 2019.

[3] E. G. Robles Morales, A.M. Medina Escudero, and C. S. Medina Escudero, "Air pollution by particulate matter and its relationship with respiratory diseases in the population of Cerro de Pasco (2010 and 2016)," Ind. Data,vol. 22, no. 1, pp. 173-186, 2019, doi: 10.15381/idata.v22i1.16533.
[4] "Electronic DevicePortable For The MeasurementOfLaCo6881751.pdf," vol. 8, no. Division of Architecture and Engineering, pp. 1-172, 2017.

[5] L. P. María Augusta and B. D. Paúl Alfonso, "Universidad Politecnica Salesiana Sede Cuenca," p. 150, 2015, [Online]. Available:

https://dspace.ups.edu.ec/bitstream/123456789/7986/1/UPSCT004855.pdf.

[6] E. Rodriguez, "STUDY FOR THE DESIGN OF AN AUTONOMOUS MOBILE ROBOT FOR MEASURING AIR AND SOIL POLLUTANTS IN THE SOUTHERN MINING CORRIDOR Work," Repos. Inst. , 2020, [Online]. Available: https://cutt.ly/sm8SKsg.

[7] J. Ramirez, "Assembly and study of the design, construction and characterization of integrated voltammetric microsensors for simultaneous analysis of gases and particulate matter air pollutants. ( For application in a time-to-air measuring station," p. 96, 2017.

[8] SHARP, "GP2Y1010AU0F Compact Optical Dust Sensor," Datasheet,pp. 1-11, 2017, [Online]. Available: http://www.sharpsme.com/download/gp2y1010au-epdf.

[9] T. Data, "MQ-2 Semiconductor Sensor for Fuel Gas," Pololu,p. 2, 2016, [Online]. Available: https://www.pololu.com/file/0J309/MQ2.pdf.

[10] H. H. Electronics, "Mq-7 carbon monoxide datasheet," pp. 2-4, 2018, [Online]. Available https://www.pololu.com/file/0J313/mq7.pdf\%0A\%0A.

[11] Sharp, "Application note of Sharp dust sensor GP2Y1010AU0F," pp. 0-6, 2013, [Online]. Available: http://www.sharpworld.com/products/devicechina/lineup/data/pdf/datasheet/gp2y1010au_appl_e.pdf.

[12] Hanwei Electronics, "MQ-7 Gas Sensor Datasheet," vol. 1, pp. 3-5, 2016.

[13] C. Nafis, "Air Quality Monitoring," 2012, Accessed: Nov. 30, 2021. [Online]. http://www.howmuchsnow.com/arduino/airquality/.

[14] D. Lancheros Cuesta, B. Galvis, and J. Pachón, "View of Portable Electronic Device for Air Pollution Measurement," vol. 8, no. 1, pp. 1-172, 2017, Accessed: Sep. 21, 2021. [Online]. Available: http://revistas.ustatunja.edu.co/index.php/ingeniomagno/article/view/ $1386 / 1280$.

[15] World Health Organization, "Ambient (Outdoor) Air Quality and Health," Sep. 2021, Accessed: Nov. 30, 2021. [Online]. Available: https://www.who.int/es/news-room/fact-sheets/detail/ambient(outdoor)-air-quality-and-health.

[16] O. Prieto, "Characterization of Particulate Material, Lead and Arsenic for the Evaluation of Air Quality in the District of IslayMatarani," Univ. Nac. St.Augustine, p. 115, 2016, [Online]. Available: http://repositorio.unsa.edu.pe/handle/UNSA/1904. 